\title{
High-Sensitivity Quantitative PCR Platform
}

BioTechniques 34:106-115 (January 2003)

\author{
Fred J. DeGraves, Dongya \\ Gao, and Bernhard \\ Kaltenboeck \\ Auburn University, \\ Auburn, AL, USA
}

\section{ABSTRACT}

Real-time PCR methods have become widely used within the past few years. However, real-time PCR is rarely used to study chronic diseases with low pathogen loads, presumably because of insufficient sensitivity. In this report, we developed an integrated nucleic acid isolation and real-time PCR platform that vastly improved the sensitivity of the quantitative detection of the intracellular bacterium, Chlamydia spp., by fluorescence resonance energy transfer realtime PCR. Determinants of the overall detection sensitivity were analyzed by extracting nucleic acids from bovine milk specimens spiked with low amounts of chlamydial organisms. Nucleic acids were optimally preserved and recovered by collection in guanidinium stabilization buffer, binding to a matrix of glass fiber fleece, and elution in low volume. Step-down thermal cycling and an excess of hot-start Taq polymerase vastly improved the robustness and sensitivity of the real-time PCR while essentially maintaining $100 \%$ specificity. The amplification of Chlamydia $23 S$ rRNA allowed for the differentiation of chlamydial species and was more robust at low target numbers than amplification of the omp1 gene. The best combined method detected single targets per a 100- $\mu \mathrm{L}$ specimen equivalent in a 5- $\mu L$ real-time PCR input. In an initial application, this high-sensitivity realtime PCR platform demonstrated a high prevalence of chlamydial infection in cattle.

\section{INTRODUCTION}

The diagnostic use of PCR in clinical microbiology has vastly increased our understanding of infectious diseases, including those induced by Chlamydia bacteria $(2,10)$. However, several factors impede the optimal diagnostic use of the high sensitivity of this method. In particular, all sensitive and specific assays that apply to diagnostic microbiology require post-PCR processing by highly skilled personnel. This is particularly true of nested PCR methods that are exceedingly sensitive to cross-contamination by "product carryover." In addition, the preservation of nucleic acid targets in specimens is often poor, and the methods of DNA or nucleic acid extraction are inadequate for the retrieval of target DNA at low concentrations (1). Finally, specimens with low amounts of chlamydiae have a Poisson-distributed sampling variability so that some aliquots from such specimens result in positive amplification, while others remain negative (14). Thus, the amount of original specimen analyzed by a single PCR may frequently be the sensitivity-limiting factor. This limitation can only be overcome by the amplification of numerous sample DNA aliquots (14).

Novel real-time fluorescent PCR methods have the potential to correct these shortcomings but have not yet been combined with nucleic acid isolation to result in high-sensitivity, highthroughput platforms suitable for wide use in clinical microbiology. We have developed a highly specific, fluorescent probe-based, single-tube LightCycler ${ }^{\circledR}$ (Roche Applied Science, Indianapolis, IN, USA) quantitative PCR method for the detection of chlamydial DNA (9). This PCR method is capable of detecting single target molecules in a sample input volume of $5 \mu \mathrm{L}$ and of quantifying chlamydial DNA with a high degree of accuracy. The single-tube format, coupled with the real-time fluorescent detection of products in the LightCycler, dramatically reduces labor and the potential for the cross-contamination of specimens by product carryover. This method is therefore ideally suited for large-scale epidemiological studies.

Here we have examined, in the context of low amounts of amplification target nucleic acids, the problems of sample stability, extraction of nucleic acids, concentration of specimen equivalents in extracted nucleic acids, optimum amplification procedures, and choice of amplification target. Using Chlamydia bacteria as a model system, we have developed a LightCycler realtime PCR platform technology that is capable of high-sensitivity and highspecificity detection of nucleic acids in a simple, high-throughput format.

\section{MATERIALS AND METHODS}

\section{Chlamydial Strains and Mouse Lung Infection}

Chlamydia psittaci strain B577 (ref no. VR-656; ATCC, Manassas, VA, USA) and $C$. pneumoniae strain CDC/CWL-029 (VR-1310) were grown in buffalo green monkey kidney cells and purified as previously described (8). C. psittaci-infected lung tissue was obtained from intranasally inoculated, six-week-old female 
Table 1. Oligonucleotide Primers and Probes Used in This Study

\begin{tabular}{|c|c|c|c|}
\hline $\begin{array}{l}\text { Primerl } \\
\text { Probe }\end{array}$ & Sequence $\left(5^{\prime} \rightarrow 3^{\prime}\right)$ & $\begin{array}{l}\text { Chlamydia } \\
\text { Reactivity }\end{array}$ & $\begin{array}{l}\text { Real-Time } \\
\text { PCR Target }\end{array}$ \\
\hline 191CHOMP & GCIYTITGGGARTGYGGITGYGCIAC & genus & omp1 \\
\hline CHOMP271 & GCTCKIGACCAITKWACICCAATGTAIGG & genus & 287 bp \\
\hline CHLANPR & LCRed640-GAYTGIGCRTATTGGAAIKMWGCICCYAA-Phosphate & genus & \\
\hline B577PR & TACATTCAACATTTCAATTTTAGGATT-6-FAM & C. psittaci B577 & \\
\hline CPECPR & AACGTTKARTTCTTGAACGCGAGGTTT-6-FAM & C. pecorum & \\
\hline CHL23SUP & GGGGTTGTAGGGTYGAGRAIAWRRGATC & genus & $23 S$ rRNA \\
\hline CHL23SDN & GAGAGTGGTCTCCCCAGATTCARACTA & genus & $168 \mathrm{bp}$ \\
\hline CHL23LCR & LCRed640-CCTGAGTAGRRCTAGACACGTGAAAC-Phosphate & genus & \\
\hline \multirow[t]{3}{*}{ CP23FLU } & ACGAAARAACAARAGACKCTAWTCGAT-6-FAM & C. psittaci & \\
\hline & & C. pneumoniae & \\
\hline & & C. pecorum & \\
\hline \multirow[t]{2}{*}{ CPN23FLU } & ACGAAAAAACAAAAGACGCTAATCGAT-6-FAM & C. pneumoniae & \\
\hline & & C. pecorum (weak) & \\
\hline CTR23FLU & ACGAAAGGAGAKMAAGACYGACCTCAAC-6-FAM & C. trachomatis & \\
\hline CHLINTUP & TGACTAGGTTGRGCAAGYRTYT & genus & 16S-23S rRNA \\
\hline CHLINTDN & AAAGACAIATAYTCTTAAACGTCTATTATTAT & genus & intergenic spacer \\
\hline CHLINLCR & LCRed640-CTTAACAAIRCAAAWGAAATAGAAT-Phosphate & genus & $163 \mathrm{bp}$ \\
\hline CPSINFLU & CGTAAACTAAATGTTTTGGAAACAA-6-FAM & C. psittaci & \\
\hline$I=$ deoxy ino & $\mathrm{e} ; \mathrm{K}=\mathrm{G} / \mathrm{T} ; \mathrm{R}=\mathrm{A} / \mathrm{G} ; \mathrm{W}=\mathrm{A} / \mathrm{T} ; \mathrm{Y}=\mathrm{C} / \mathrm{T}$ & & \\
\hline
\end{tabular}

BALB/c mice (8). Mouse lungs were homogenized in disposable tissue grinders (Closed Tissue Grinder System ${ }^{\circledR}$; Fisher HealthCare, Houston, TX, USA) to $10 \%(\mathrm{w} / \mathrm{v})$ suspensions in RNA/DNA Stabilization Reagent for Blood/Bone Marrow ${ }^{\circledR}$ (Roche Applied Science).

All animal experiments were performed in accordance with protocols approved by the Auburn University Institutional Animal Care and Use Committee. Data were analyzed by a twotailed Student's $t$ test and least-square linear regression algorithm.

\section{Nucleic Acid Extraction}

After initial studies with several commercially available kits, total nucleic acids were extracted with the High Pure PCR Template Preparation Kit ${ }^{\circledR}$ (Roche Applied Science). All extractions were performed without the use of the SDS/EDTA-based Tissue Lysis Buffer from the kit. Instead, 10\% proteinase $\mathrm{K}$ solution was added directly to specimens lysed $1: 10$ in RNA/DNA Stabilization Reagent or 1:1 in High Pure Binding Buffer [6 M guanidine$\mathrm{HCl}, 10 \mathrm{mM}$ urea, 20\% (v/v) Triton ${ }^{\circledR}$
$\mathrm{X}-100,10 \mathrm{mM}$ Tris-HCl, pH 4.4]. Thus, the proteinase $\mathrm{K}$ digestion and subsequent binding of nucleic acids to the glass fiber fleece matrix of the High Pure kit was performed in both variations of the method at acidic $\mathrm{pH}$ and approximately $2.7 \mathrm{M}$ guanidinium concentration. The use of the concentrated High Pure Binding Buffer is advantageous for the preservation of dilute fluid specimens such as urine, serum, or milk. Further modifications of the High Pure extraction are described in the Results section. Total nucleic acids were also isolated with the mRNA Isolation $\mathrm{Kit}^{\circledR}$ for Blood/Bone Marrow (Roche Applied Science) using modifications of the manufacturer's protocol. In all protocols, nucleic acids were eluted or dissolved in $10 \mathrm{mM}$ Tris- $\mathrm{HCl}, \mathrm{pH} 8.5$, $0.1 \mathrm{mM}$ EDTA (TE buffer).

\section{Real-time Fluorescence Resonance Energy Transfer PCR}

All real-time PCRs were performed in volumes of $15 \mu \mathrm{L}$ reaction master mixture and $5 \mu \mathrm{L}$ sample aliquot in LightCycler glass capillaries in a LightCycler Real-Time Thermal Cycler (9). The PCR buffer was $4.5 \mathrm{mM} \mathrm{MgCl}_{2}, 50 \mathrm{mM} \mathrm{KCl}$,
$20 \mathrm{mM}$ Tris-HCl, $\mathrm{pH}$ 8.4, supplemented with $0.05 \%$ each Tween ${ }^{\circledR} 20$ and Non$\operatorname{idet}^{\mathrm{TM}} \mathrm{P}-40$, and $0.03 \%$ acetylated BSA (Roche Applied Science). Nucleotides were used at $0.2 \mathrm{mM}$ (dATP, dCTP, $\mathrm{dGTP}$ ) and $0.6 \mathrm{mM}$ (dUTP). For each $20-\mu \mathrm{L}$ total reaction volume, we used 1.5 U hot-start Platinum ${ }^{\circledR}$ Taq DNA polymerase (Invitrogen, Carlsbad, CA, USA) and 0.2 U heat-labile uracil-DNA glycosylase (UNG) (Roche Applied Science). Heat-labile UNG is active at room temperature and is inactivated at $50^{\circ} \mathrm{C}$. This allows for the use of UNG carryover prevention in one-step real-time RT-PCR.

Primers and probes were obtained from Operon Technologies (Alameda, CA, USA). LightCycler Red 640 (LCRed640) probes were 5' labeled and HPLC purified, and carboxyfluorescein (6-FAM) probes were $3^{\prime}$ labeled and used unpurified. Primers were used at 1 $\mu \mathrm{M}$ [except for the Chlamydia ompl PCR (9)], LCRed640 probes were used at $0.2 \mu \mathrm{M}$, and 6-FAM probes were used at $0.1 \mu \mathrm{M}$. In all real-time PCRs, Chlamydia genus-specific primers were combined with genus-specific LCRed640-labeled probes and with Chlamydia species- or strain-specific 6-FAM-labeled probes, as listed in Table 1. 
For each real-time PCR, the reaction master mixture was freshly assembled from separate stocks of distilled water, $5 \times$ PCR buffer, 5x oligonucleotides (primers and probes) in TE buffer, 50× PCR Nucleotide Mix PLUS ${ }^{\circledR}$ (Roche Applied Science), Platinum Taq DNA polymerase, and UNG.

Thermal cycling consisted of a 2min denaturation step at $95^{\circ} \mathrm{C}$, followed by 18 high-stringency step-down thermal cycles, 40 low-stringency fluorescence acquisition cycles, and melting curve determination between $50^{\circ} \mathrm{C}$ and $80^{\circ} \mathrm{C}$. The specific thermal protocol for the ompl real-time PCR was $6 \times$ for $12 \mathrm{~s}$ at $60^{\circ} \mathrm{C}, 11 \mathrm{~s}$ at $72^{\circ} \mathrm{C}, 0 \mathrm{~s}$ at $95^{\circ} \mathrm{C} ; 9 \times$ for $12 \mathrm{~s}$ at $58^{\circ} \mathrm{C}, 11 \mathrm{~s}$ at $72^{\circ} \mathrm{C}$, $0 \mathrm{~s}$ at $95^{\circ} \mathrm{C} ; 3 \times$ for $12 \mathrm{~s}$ at $56^{\circ} \mathrm{C}, 11 \mathrm{~s}$ at $72^{\circ} \mathrm{C}, 0 \mathrm{~s}$ at $95^{\circ} \mathrm{C} ; 40 \times$ for $8 \mathrm{~s}$ at $50^{\circ} \mathrm{C}$, and fluorescence acquisition for $11 \mathrm{~s}$ at $72^{\circ} \mathrm{C}$ and $0 \mathrm{~s}$ at $95^{\circ} \mathrm{C}$. The parameters for the 23S rRNA real-time PCR were $6 \times$ for $12 \mathrm{~s}$ at $64^{\circ} \mathrm{C}, 8 \mathrm{~s}$ at $72^{\circ} \mathrm{C}, 0 \mathrm{~s}$ at $95^{\circ} \mathrm{C} ; 9 \times$ for $12 \mathrm{~s}$ at $62^{\circ} \mathrm{C}, 8 \mathrm{~s}$ at $72^{\circ} \mathrm{C}$, $0 \mathrm{~s}$ at $95^{\circ} \mathrm{C} ; 3 \times$ for $12 \mathrm{~s}$ at $60^{\circ} \mathrm{C}, 8 \mathrm{~s}$ at $72^{\circ} \mathrm{C}, 0 \mathrm{~s}$ at $95^{\circ} \mathrm{C} ; 40 \times$ for $8 \mathrm{~s}$ at $54^{\circ} \mathrm{C}$, and fluorescence acquisition for $8 \mathrm{~s}$ at $72^{\circ} \mathrm{C}$ and $0 \mathrm{~s}$ at $95^{\circ} \mathrm{C}$. The parameters for the 16-23S rRNA intergenic spacer real-time PCR were $6 \times$ for $12 \mathrm{~s}$ at $61^{\circ} \mathrm{C}, 8 \mathrm{~s}$ at $72^{\circ} \mathrm{C}, 0 \mathrm{~s}$ at $95^{\circ} \mathrm{C} ; 9 \times$ for $12 \mathrm{~s}$ at $59^{\circ} \mathrm{C}, 8 \mathrm{~s}$ at $72^{\circ} \mathrm{C}, 0 \mathrm{~s}$ at $95^{\circ} \mathrm{C}$; $3 \times$ for $12 \mathrm{~s}$ at $57^{\circ} \mathrm{C}, 8 \mathrm{~s}$ at $72^{\circ} \mathrm{C}, 0 \mathrm{~s}$ at $95^{\circ} \mathrm{C}$; $40 \times$ for $8 \mathrm{~s}$ at $52^{\circ} \mathrm{C}$, and fluorescence acquisition for $8 \mathrm{~s}$ at $72^{\circ} \mathrm{C}$ and $0 \mathrm{~s}$ at $95^{\circ} \mathrm{C}$. These protocols are designed for quantitative determination of 10000 or fewer target molecules. The signal for 10000 targets typically is distinguishable from the background after about six fluorescence acquisition cycles (total of 24 cycles). Data were displayed and analyzed as 640:530 nm fluorescence ratios.

For one-step real-time RT-PCR, a reverse transcription step at $50^{\circ} \mathrm{C}$ for 20 min was included before the initial denaturation at $95^{\circ} \mathrm{C}$. For each $20 \mu \mathrm{L}$ real-time RT-PCR, we used $0.25 \mathrm{U} \mathrm{Su}$ perScript $^{\circledR}$ II Reverse Transcriptase (Invitrogen).

For use as quantitative standards, $C$. psittaci B577 and C. pneumoniae DNA were extracted from purified elementary body preparations by the High Pure method, quantified by the PicoGreen ${ }^{\circledR}$ DNA fluorescence assay (Molecular Probes, Eugene, OR, USA), and used at
$10000,1000,100,10$, and 0 genome copies per $5 \mu \mathrm{L}$ in a background of 100 ng purified salmon sperm DNA in TE buffer. Crude chlamydial DNAs extracted from infected yolk sac tissue $(12,13)$ were used to analyze the specificity of detection of the Chlamydia 23S rRNA real-time PCRs.

\section{RESULTS}

\section{Extraction of Nucleic Acids}

In preliminary real-time PCR experiments with clinical specimens and $C$. psittaci-infected mouse lungs, it was obvious that sample homogenization in cell culture media and/or freeze-thaw cycles of samples led to a rapid loss of chlamydial target DNA, as detected by Chlamydia ompl-fluorescence resonance energy transfer (FRET) real-time PCR. In particular, we examined specimens in parallel by DNA extraction before and after cryostorage. Specimens that contained low target numbers before freezing typically became negative after cryostorage. To achieve the optimum PCR sensitivity for the detection of genomic chlamdial DNA, the preservation of DNA from degradation would be critically important, similar to the importance of RNA preservation for the optimum performance of RT-PCR (15). This prompted us to explore the effectiveness of the commercially available RNA/DNA Stabilization Reagent for Blood/Bone Marrow. This reagent is based on the denaturation of proteins in a concentrated solution of guanidinium isothiocyanate and a reducing agent, as introduced by Chirgwin et al. (3) for the inactivation of ribonuclease during RNA isolation. In preliminary experiments, we prepared $10 \%(\mathrm{w} / \mathrm{v})$ suspensions of lungs from mice infected with C. psittaci B577 in this reagent and performed $C$. psittaci B577 omp1 FRET real-time PCR analyses with DNA extracted from these samples before freezing and after several freeze-thaw cycles. Within the experimental variance, the number of chlamydial targets did not decrease with cryostorage or when subjected to additional freeze-thaw cycles. In contrast, chlamydial PCR targets in DNA extracted from infected lungs homoge- nized in PBS or TBS were extensively degraded $(50 \%-90 \%$ reduction) if DNA extraction after homogenization was delayed by more than 5 min or if frozen lung suspensions were thawed repeatedly (data not shown). Based on this initial confirmation of common experience in nucleic acid isolation, we routinely collected all specimens for PCR analysis in this RNA/DNA stabilization reagent.

As a next step, we analyzed the suitability of widely used commercial kits for the complete isolation of low concentrations of DNA or total nucleic acids for high-sensitivity real-time PCR detection of chlamydiae. Bovine milk, a difficult matrix for nucleic acid extraction, was diluted 1:10 in RNA/DNA Stabilization Reagent. A suspension of C. psittaci B577-infected mouse lung stabilized in the same reagent was added to 7000 chlamydial genomes $/ \mathrm{mL}$ final dilution, corresponding to 70000 chlamydial genomes/mL original specimen. DNA was extracted using three commercially available kits. These kits utilize different approaches for nucleic acid purification:nucleic acid binding in acidic chaotropic buffer to a glass fiber fleece (17), followed by washing and elution at alkaline $\mathrm{pH}$; binding to a porous silica matrix in place of glass fiber; and selective precipitation of nucleic acids. Spiked milk was extracted according to the manufacturer's instructions, and the total nucleic acids were recovered in TE buffer. Duplicate $5-\mu \mathrm{L}$ aliquots of triplicate extractions with each kit were analyzed by $C$. psittaci B577 omp1 FRET real-time PCR. The results in Table 2 unambiguously demonstrate that only the extraction by glass fiber fleece binding and elution recovers minute amounts of chlamydial target DNA. Based on these results, we conducted additional experiments with the High Pure method to further improve detection sensitivity.

\section{Enrichment of Chlamydial Target DNA}

The previous set of experiments had clearly shown the principal limitation for the sensitivity of any real-time PCR that, despite a very high number of 70000 targets/mL original sample, the theoretically detectable number of 
Table 2. Evaluation of Nucleic Acid Extraction Methods

\begin{tabular}{|c|c|c|c|c|c|}
\hline $\begin{array}{l}\text { C. psittaci B577 } \\
\text { Genomes/mL } \\
\text { Original Milk Sample }\end{array}$ & $\begin{array}{l}\text { Nucleic Acid } \\
\text { Extraction }\end{array}$ & $\begin{array}{c}\text { Sample } \\
\text { Equivalent/ } \\
\text { PCR }(\mu \mathrm{L})\end{array}$ & $\begin{array}{c}\text { Theoretical } \\
\text { Chlamydia } \\
\text { Genomes/PCR }\end{array}$ & $\begin{array}{c}\text { Observed } \\
\text { Chlamydia } \\
\text { Genome/PCR ( } \pm \text { SEM) }\end{array}$ & $\begin{array}{l}\text { Percent } \\
\text { Recovery } \\
\text { ( } \pm \text { SEM) }\end{array}$ \\
\hline \multirow{3}{*}{70000} & glass fiber fleece & 0.5 & 35 & $29.1 \pm 3.1$ & $83.2 \pm 8.9$ \\
\hline & porous silica matrix & 0.25 & 17.5 & $0.1 \pm 0.1$ & $0.3 \pm 0.3$ \\
\hline & selective precipitation & 1.5 & 105 & $1.0 \pm 0.4$ & $1.0 \pm 0.4$ \\
\hline
\end{tabular}

genomes per real-time PCR was only 35 (Table 2). To overcome this limitation, it is necessary to $(i)$ concentrate nucleic acids extracted from a large sample into a small volume; (ii) specifically enrich for target nucleic acids; or (iii) use a combination of both methods. We addressed these questions by comparing the standard High Pure extraction procedure to several approaches for enhancing the number of chlamydial targets/real-time PCR. We evaluated these methods in a dilution series of stabilized milk with 70000 , $7000,700,70,7$, or 0 chlamydial genomes $/ \mathrm{mL}$.

To concentrate specimen nucleic acids in the High Pure extraction procedure, we added four consecutive 400$\mu \mathrm{L}$ loads of specimen lysate instead of a single load to the sample reservoir. We then examined if the direct elution of the nucleic acids with $2 \times 200 \mu \mathrm{L} \mathrm{TE}$ into centrifugal ultrafiltration devices (10000 MW cut-off microconcentrator; Amicon, Beverly, MA, USA) by inserting the High Pure sample reservoir into the microconcentrator, followed by centrifugal concentration at $13000 \times g$ for $20 \mathrm{~min}$ to a $20-\mu \mathrm{L}$ volume, allowed for the effective concentration of nucleic acids. This loading (repeated four times) and direct microconcentration approach increased the concentration of target DNA by about 60 -fold at the highest chlamydial loads $[1246 \pm 103(\mathrm{SEM})$ vs. $19.6 \pm 4$ (SEM) genomes detected per real-time PCR]. At 70 chlamydial genomes $/ \mathrm{mL}$ original milk, the concentration method detected $3.9 \pm 1$ genomes/real-time PCR, while the non-concentrated sample aliquots remained negative.

Next, we examined if the enrichment of nucleic acids from large sample volumes of stabilized milk further increased detection sensitivity. Nucleic acids in stabilized milk were bound to magnetic glass particles and eluted in low volume before the standard High Pure extraction of the eluate. We adapted the mRNA Isolation Kit for Blood/Bone Marrow for this experiment. This approach failed to substantially enrich for chlamydial DNA, particularly at low amounts of chlamydial targets, and target recovery was only about one tenth of the standard High Pure extraction.

In a final test, we combined magnetic glass particle DNA concentration with the specific enrichment of chlamydial ompl nucleic acid targets by hybridization capture to the 5'-biotinylated primers 191CHOMP and CHOM271, followed by streptavidin magnetic bead extraction and low-volume elution. For this purpose, we modified the protocol of the mRNA Isolation Kit for Blood/Bone Marrow by replacing the biotinylated oligo $(\mathrm{dT})_{20}$ reagent with the Chlamydia ompl reagents. We found poor target recovery of less than $1 \%$, which excluded the DNA hybridization capture method from use in high-sensitivity real-time PCR.

In summary, both the standard and the microconcentrator High Pure extractions offer high target recovery but not any of the other enrichment methods tested. The microconcentrator extraction method exhibits high recovery at very low chlamydial genome copy number. For this reason, we chose this method to explore further options for high-sensitivity real-time PCR.

\section{Optimal Real-Time PCR Methodology}

We saw potential for further improvements by evaluating the detection of genomic targets combined with the detection of their transcripts. Glass fiber binding and elution by the High Pure method isolated all specimen nucleic acids, including mRNA. Reverse transcription before real-time PCR might therefore increase the detection sensitivity by detecting transcripts in addition to the genomic copy of the gene. The chlamydial rRNA operon contains the genes encoding the chlamydial $16 \mathrm{~S}$ and $23 \mathrm{~S}$ rRNA $(11,16)$, which are structural components of the ribosome and therefore stably present in high copy numbers in chlamydial cells. The intervening sequence between $16 \mathrm{~S}$ and 23S rRNA (16S-23S rRNA intergenic spacer) is highly transcribed but rapidly degraded. These genes are highly conserved, thus offering the potential for genus-specific detection of chlamydiae, and also contain sufficient polymorphisms for differentiation, in particular the $16 \mathrm{~S}-23 \mathrm{~S}$ rRNA intergenic spacer $(2,4-6)$.

We first established real-time PCR methods for chlamydial 23S rRNA and 16S-23S rRNA intergenic spacer sequences (Table 1). When we attempted to establish a one-step, single-tube realtime RT-PCR methodology, we encountered problems with detection sensitivity due to excessive background amplification. To solve this problem, we converted the thermal cycling strategy from a single annealing temperature approach (9) to a step-down approach (7) with carefully calibrated temperatures and step-down cycle numbers. Following 18 stringent stepdown cycles, we performed 40 additional low-stringency fluorescence acquisition cycles with a single annealing temperature. This thermal cycling approach substantially improved all FRET real-time PCRs, including the Chlamydia omp1 method (9). It was also necessary to minimize the amount of reverse transcriptase for one-step 
Table 3. Evaluation of Chlamydia Real-Time PCR for Different Chlamydial Target Genes Performed with or without One-Step Reverse Transcription

\begin{tabular}{|c|c|c|c|c|}
\hline $\begin{array}{c}\text { C. psittaci B577 } \\
\text { Genomes/mL } \\
\text { Original Milk Sample }\end{array}$ & $\begin{array}{l}\text { Chlamydia } \\
\text { Real-Time } \\
\text { PCR }^{\mathrm{a}}\end{array}$ & $\begin{array}{c}\text { Theoretical } \\
\text { Chlamydia } \\
\text { Genomes/PCR }\end{array}$ & $\begin{array}{c}\text { Observed } \\
\text { Chlamydia Genomes/ } \\
\text { PCR ( } \pm \text { SEM) }\end{array}$ & $\begin{array}{l}\text { Percent } \\
\text { Recovery } \\
\text { ( } \pm \text { SEM) }\end{array}$ \\
\hline \multirow{6}{*}{700} & omp1 & & $5.8 \pm 0.7$ & $20.7 \pm 2.5$ \\
\hline & omp1+RT & & $10.4 \pm 0.9$ & $37.1 \pm 3.1$ \\
\hline & $23 \mathrm{~S}$ rRNA & 28 & $9.2 \pm 0.9$ & $32.9 \pm 3.3$ \\
\hline & 23S rRNA+RT & & $48.7 \pm 4.5$ & $173.8 \pm 16.2$ \\
\hline & 16S-23S rRNA intergen & & $10.9 \pm 3.6$ & $38.8 \pm 12.8$ \\
\hline & 16S-23S rRNA intergen+RT & & $17.0 \pm 7.2$ & $60.7 \pm 25.6$ \\
\hline \multirow{6}{*}{70} & omp1 & & $0.2 \pm 0.1$ & $5.8 \pm 4.8$ \\
\hline & omp1+RT & & $0.6 \pm 0.2$ & $21.4 \pm 8.1$ \\
\hline & 23S rRNA & 2.8 & $0.7 \pm 0.2$ & $26.1 \pm 8.2$ \\
\hline & 23S rRNA+RT & & $7.0 \pm 1.8$ & $249 \pm 65.7$ \\
\hline & 16S-23S rRNA intergen & & $0.1 \pm 0.04$ & $2.8 \pm 1.6$ \\
\hline & 16S-23S rRNA intergen+RT & & 0 & 0 \\
\hline \multirow{6}{*}{7} & omp1 & & 0 & 0 \\
\hline & omp1+RT & & $0.1 \pm 0.1$ & $17.9 \pm 17.9$ \\
\hline & 23S rRNA & 0.28 & $0.3 \pm 0.2$ & $106 \pm 69.3$ \\
\hline & 23S rRNA+RT & & $2.6 \pm 1.7$ & $937 \pm 620$ \\
\hline & 16S-23S rRNA intergen & & 0 & 0 \\
\hline & 16S-23S rRNA intergen+RT & & 0 & 0 \\
\hline
\end{tabular}

real-time RT-PCR. High amounts of SuperScript II reverse transcriptase strongly increased the number of detected chlamydial genomes at high copy input of nucleic acids of purified elementary bodies but rendered the detection of low target numbers impossible because of high background amplification. However, with a low input of 0.25 U SuperScript reverse transcriptase, the detected quantity of 10 genomes of $C$. psittaci B577 in the Chlamydia 23S rRNA real-time PCR increased to 24 in the real-time RTPCR (Figure 1).

Next, we evaluated the detection limits of Chlamydia omp1, 23S rRNA, and 16S-23S rRNA intergenic spacer real-time PCRs with and without onestep reverse transcription in a dilution series of stabilized bovine milk spiked with C. psittaci B577-infected mouse lung tissue (Table 3). Nucleic acids were extracted by the four-fold loading of High Pure sample reservoirs, microconcentrator elution, and concentration to $20 \mu \mathrm{L}$. Duplicate real-time PCRs of triplicate samples were performed with and without the one-tube reverse transcription of the assembled reactions.

\begin{tabular}{|r|r|r|}
\hline Standard & \multicolumn{1}{|c|}{$\mathbf{R T}$} & $\mathbf{+} \mathbf{R T}$ \\
\hline 10,000 & 10,410 & 10,330 \\
1,000 & 943.3 & 949. \\
100 & 98.3 & 135.4 \\
10 & 10.3 & 24. \\
0 & 0 & \\
\hline
\end{tabular}

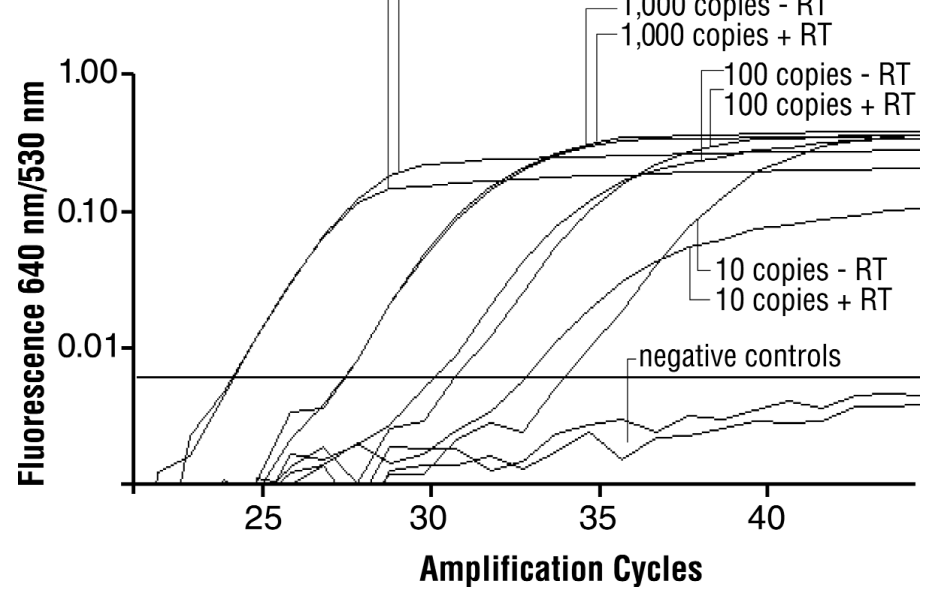

Figure 1. Evaluation of the effect of one-step reverse transcription on the sensitivity of the Chlamydia 23S rRNA real-time PCR. C. psittaci B577 standards at $10000,1000,100,10$, or 0 target genomes/real-time PCR were amplified without (-RT) or with (+RT) one-step reverse transcription. Reverse transcription was performed with $0.25 \mathrm{U}$ SuperScript II reverse transcriptase per real-time PCR for $20 \mathrm{~min}$ at $50^{\circ} \mathrm{C}$ in the real-time PCR glass capillary. At 10 target copies, one-step reverse transcription improves the sensitivity of the C. psittaci/pecorum/pneumoniae $23 \mathrm{~S}$ rRNA real-time PCR by 2.5 -fold but reduces the signal-to-noise ratio of the assay at 10 targets. The use of higher amounts of SuperScript II reverse transcriptase improved detection at high target numbers but rendered low target numbers undetectable, thus reducing the overall sensitivity of the assay. 
The results clearly indicate that the $23 \mathrm{~S}$ rRNA target is optimal for reliable high-sensitivity detection of chlamydial genomic DNA (Table 3). The data also demonstrate substantially increased target detection with one-step reverse transcription, particularly at time RT-PCR detects approximately 10 times more 23S rRNA targets than the real-time PCR with no reverse transcription. However, the real-time RTPCR detected higher numbers of targets in samples that were also positive in the real-time PCR. Thus, real-time RT-PCR did not really increase the detection of positive specimens but only the number of detected targets in specimens that were positive in both methods. Based on these results, we see a need for the large-scale comparison of both methods to reliably assess the value of real-time RT-PCR.

\section{Specificity of the Chlamydia 23S rRNA Real-Time PCR}

We chose the 23S rRNA real-time PCR as our standard method and evaluated as a next step the specificity of this assay and of the various 6-FAM-lalow target numbers, in which the real-

beled probes that are combined with the genus-specific set of CHL23SUP, CHL23SDN, and CHL23LCR primers and probes (Table 1). Our routinely used 6-FAM probe CP23FLU was designed to hybridize with C. psittaci, $C$. pneumoniae, and $C$. pecorum sequences but not with $C$. trachomatis. The melting curve analysis of the saturation amplification products of the crude DNAs of several chlamydial strains confirmed this specificity (Figure 2). The $\mathrm{T}_{\mathrm{m}}$ peaks for $C$. psittaci and $C$. pneumoniae strains were at approximately $55^{\circ} \mathrm{C}$, while a distinct set of melting peaks for $C$. pecorum strains centered around $54^{\circ} \mathrm{C}$, allowing for the limited differentiation of chlamydial species. The amplification of $C$. trachomatis and irrelevant control bacteria did not yield any hybridization signal. When observed from early positivity to late saturation of the real-time PCR, melting peaks initially were seen at temperatures of approximately $58.5^{\circ} \mathrm{C}$ (C. psittaci and C. pneumoniae) or $57^{\circ} \mathrm{C}(C$. pecorum). These peaks shifted to the lower values over the course of the real-time PCR, from early positive to late-saturated reactions.

We also examined the specificities

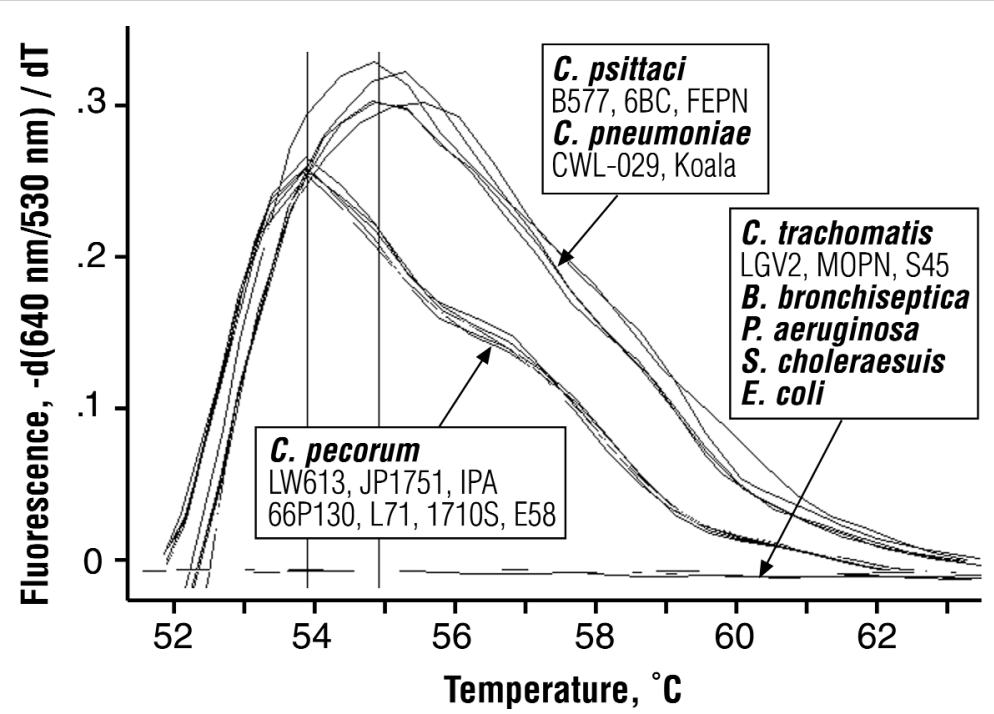

Figure 2. Specificity of the $C$. psittaci/pecorum/pneumoniae 23S rRNA FRET real-time PCR. Melting curves of the amplification products of various chlamydial strains in the C. psittaci/pecorum/pneumoniae FRET real-time PCR were acquired. Crude chlamydial DNAs (12) were diluted from 10000 to 1000 genome copies per $5 \mu \mathrm{L}$ real-time PCR input. Amplification was performed with primers CHL23SUP and CHL23SDN and probes CHL23LCR and CP23FLU. Saturated PCRs of C. psittaci and C. pneumoniae templates yielded melting curves with $\mathrm{T}_{\mathrm{m}}$ peaks at approximately $55^{\circ} \mathrm{C}$, which were clearly distinguished from C. pecorum peaks at approximately $54^{\circ} \mathrm{C}$. Templates of C. trachomatis and DNA of irrelevant control bacteria did not yield any hybridizing amplification products. of the $C$. pneumoniae probe CPN23FLU and the $C$. trachomatis probe CTR23FLU with the same set of control DNAs (data not shown). CPN23FLU exhibited weak cross-reactivity with $C$. pecorum DNA. However, the wide difference between the $C$. pneumoniae $\mathrm{T}_{\mathrm{m}}\left(63^{\circ} \mathrm{C}\right)$ and the C. pecorum $\mathrm{T}_{\mathrm{m}}\left(55^{\circ} \mathrm{C}\right)$ allows for unambiguous species discrimination. CTR23FLU hybridized only to $C$. trachomatis DNA ( $\mathrm{T}_{\mathrm{m}}$ : $65.4^{\circ} \mathrm{C}, \mathrm{LGV} 2 ; 66.3^{\circ} \mathrm{C}, \mathrm{MoPn}$; and $\left.61.5^{\circ} \mathrm{C}, \mathrm{S} 45\right)$. Collectively, these data indicated excellent specificity of the chlamydial 23S rRNA FRET realtime PCR and an easy adaptation for differentiation of alleles of interest.

\section{Adaptation of the Real-Time PCR Platform for High-Throughput Sample Processing}

Before the large-scale application of the Chlamydia 23S rRNA real-time PCR detection platform, we sought to increase the robustness of sample processing. Several issues required close attention: $(i)$ the stability of collected specimens under field conditions; (ii) the complicated procedure of inserting the High Pure reservoirs into microconcentrators; and (iii) the associated difficulty of maintaining an elution temperature of $72^{\circ} \mathrm{C}$, which is essential for high nucleic acid recovery.

We addressed the issue of sample stability in an experiment in which fresh milk was spiked with C. pneumoniae elementary bodies. We used $C$. pneumoniae because fresh cow milk was frequently positive for $C$. psittaci in the Chlamydia 23S rRNA real-time PCR, which is consistent with the high prevalence of this infection in cattle. The spiked milk was stabilized by a 1:1 dilution with High Pure Binding Buffer and stored for $3,6,9$, or 14 days at $-85^{\circ} \mathrm{C}, 4^{\circ} \mathrm{C}, 25^{\circ} \mathrm{C}, 37^{\circ} \mathrm{C}$, or $65^{\circ} \mathrm{C}$. DNA was filter-concentrated to $25 \mu \mathrm{L}$, and duplicates of triplicate samples were analyzed by $C$. pneumoniae $23 \mathrm{~S}$ rRNA FRET real-time PCR. The results of a multiple regression analysis show minor reduction of recovered C. pneumoniae genomes with increasing storage temperature and time (Figure 3 ). Twenty percent of the variation in detection of $C$. pneumoniae was caused by storage time, $24 \%$ was caused by storage 
temperature, and the remaining 56\% was caused by storage-independent factors such as the Poisson distribution of PCR input genomes and assay variance. Overall, the results of this experiment indicate that chlamydial nucleic acids are well preserved during the first two weeks after sampling even when stored at high temperature. The critical comparison between samples stored for two weeks at $-85^{\circ} \mathrm{C}$ versus those stored at room temperature resulted in $2.23 \pm$ 0.44 and $1.76 \pm 0.29$ genomes/PCR, respectively. These differences are not statistically significant. The samples stored for 38 days at room temperature contained $2.16 \pm 0.28$ genomes/PCR. These data clearly indicate that sample nucleic acid stability after two weeks is not significantly affected by long-term storage at room temperature. Therefore, we consider the guanidinium stabilization method as robust under field conditions, combining facile sample collection and shipment with optimum target preservation.

To address the issue of easy and robust nucleic acid elution, we re-examined our initial assumption; that is, the need for high volume elution from the High Pure glass fiber fleece to avoid insufficient elution in low buffer volume.
In three independent experiments, we compared the extraction of milk spiked with 30 C. pneumoniae elementary bodies/mL by microconcentrator elution with $2 \times 200 \mu \mathrm{L}$ TE buffer and concentration to $40 \mu \mathrm{L}$ to direct elution with $2 \times$ $20 \mu \mathrm{L}$. To insure the complete recovery at low volume, we equilibrated the High Pure sample reservoirs at $72^{\circ} \mathrm{C}$, transferred heated buffer to the reservoirs, and incubated the reservoirs on an Eppendorf ${ }^{\circledR}$ Thermomixer R (Brinkmann Instruments, Westbury, NY, USA) for an additional $5 \mathrm{~min}$ before we obtained the eluate by a 1-min centrifugation at $13000 \times g$. We obtained a total of $86.8 \pm$ $8.8 \%$ recovery of $C$. pneumoniae with the microconcentrator elution method and $90.6 \pm 5.7 \%$ recovery in the lowvolume method. Thus, the elution methods are not statistically different $(P=$ 0.71 ), and the low-volume elution is therefore preferable because it does not require the additional manipulation of the eluted DNA.

\section{DISCUSSION}

In this study, we investigated the critical parameters that affect the overall sensitivity of detection by fluorescent probe real-time PCR of chlamydial nucleic acids that are typically present in specimens at very low concentrations. This approach will facilitate the application of real-time PCR microbiological diagnosis in clinical settings with the simplicity of the closed-tube format and the excellent specificity of hybridization probe real-time PCR amplification coupled with high sensitivity.

The use of guanidinium buffers successfully preserved the integrity of even low amounts of target nucleic acids and allowed for a simple and robust format of sample collection that tolerates lengthy storage or shipment at ambient temperatures. Glass fiber binding and elution using the High Pure extraction method was clearly best suited for the optimum recovery of minute amounts of nucleic acids. This method appears equally well suited for the detection of viral nucleic acids. The mechanical disruption of protective cell walls might release nucleic acids from Gram-positive bacteria, fungi, and parasites, and thus further increase the spectrum of detectable pathogens.

A typical limitation to sensitivity, low amounts of sample equivalents per real-time PCR input, was alleviated by sequentially loading several sample
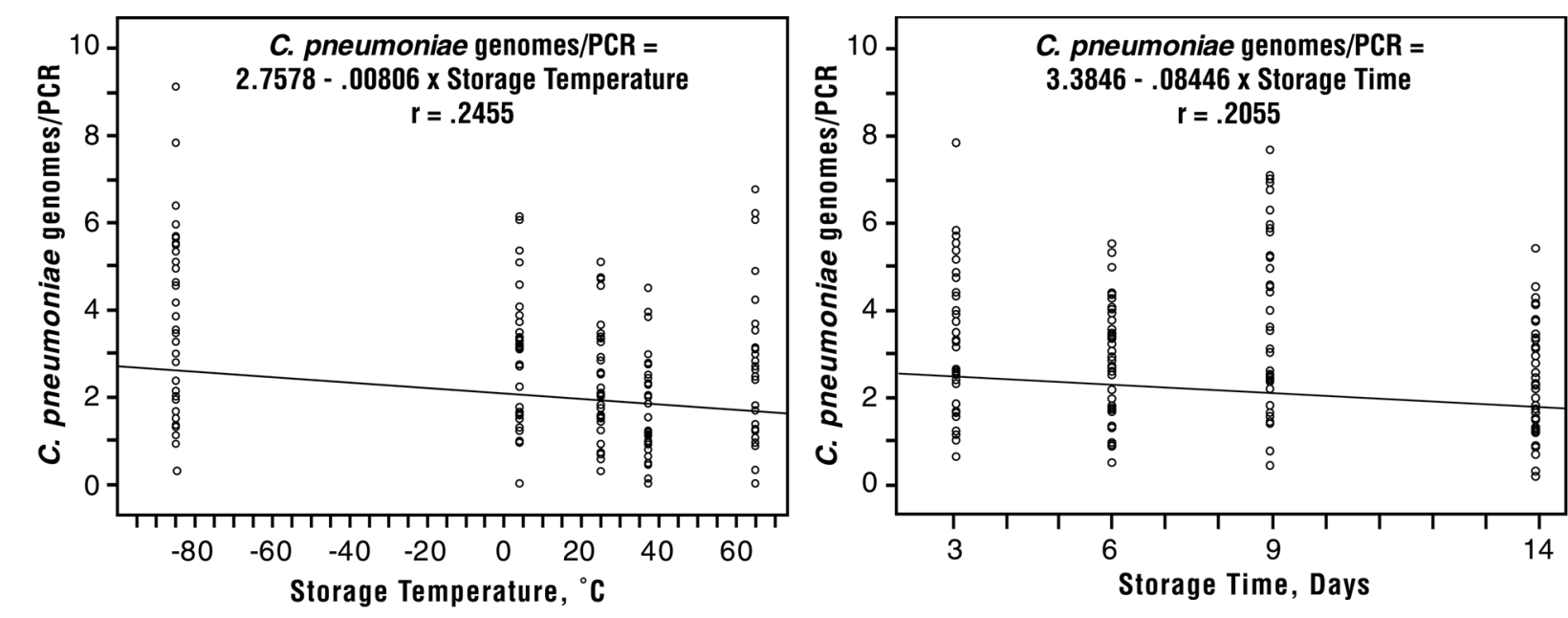

Figure 3. Dependence of $C$. pneumoniae DNA recovery on temperature and time of short-term storage of the stabilized milk sample. Fresh milk was spiked with $C$. pneumoniae elementary bodies diluted in sucrose-phosphate-glutamate buffer to 30 genomes/mL. Six-hundred microgram aliquots were stabilized by a 1:1 dilution with High Pure Binding Buffer and stored in triplicates under the indicated temperature and time conditions. DNA was extracted with the High Pure kit, eluted twice with $200 \mu \mathrm{L}$ TE buffer, and filter-concentrated to $25 \mu \mathrm{L}$. Aliquots $(5 \mu \mathrm{L})$ were analyzed by $C$. pneumoniae $23 \mathrm{~S}$ rRNA FRET realtime PCR. The data show a range of 0-8.6 C. pneumoniae genome copies per PCR, at a theoretical mean of 3.6 copies, which indicates a Poisson distribution of PCR input targets. Multiple linear regression analysis described the dependence of the detection of C. pneumoniae on storage time and temperature as $C$. pneumoniae genomes $/ \mathrm{PCR}=3.42-0.08097 \times$ days $-0.00782 \times{ }^{\circ} \mathrm{C}, \mathrm{r}=0.315$. Simple regression lines are shown for the time and temperature dependence of recovery of $C$. pneumoniae within the first two weeks after sampling. The results indicate the high preservation of the nucleic acid targets in the stabilized sample, with minor decreases for high temperature and long-term storage. 
aliquots into the reservoir of the High Pure extraction matrix and by concentrating the elution volume, or more robustly, by carefully controlling the lowvolume elution of nucleic acids. Unexpectedly, additional steps for enrichment were ineffective. Collectively, our analyses suggest that the simplicity of the extraction method using the least possible number of pipetting steps is important for high recovery of minimal amounts of target nucleic acids. The best combined methods for specimen preparation, nucleic acid extraction, and target nucleic acid concentration typically result in approximately 100 $\mu \mathrm{L}$ specimen equivalent per $5 \mu \mathrm{L}$ realtime PCR input. Given the reliable detection of single targets by real-time PCR, this results in an overall sensitivity of approximately 1 target copy per $100 \mu \mathrm{L}$ original specimen volume in a single real-time PCR. However, the overall sensitivity is dependent only on the total sum of the multiple real-time PCRs that can be assayed from the specimen (14).

Step-down thermal cycling and an excess of hot-start Taq DNA polymerase vastly improved the robustness and sensitivity of the real-time PCR while maintaining essentially $100 \%$ specificity. Chlamydial 23S rRNA offered the most robust assay at low target numbers. The influence of one-step reverse transcription on real-time PCR sensitivity remains equivocal and deserves evaluation with large sample numbers.

Several advantages of the FRET real-time PCR method compared to hybridization PCR methods include: $(i)$ the design of the adjacent probes, each carrying only a single fluorescent label, is generally easy and the use is robust and (ii) the increased length of the hybridizing target sequence enhances the differentiation capability of FRET realtime PCR in conjunction with probes of broad and narrow specificity. Our FRET real-time PCR platform also allows for easy switching to other realtime PCR targets. To adjust between different real-time PCRs or different probe batches of the same real-time PCR, we do not change the assay chemistry (e.g., $\mathrm{MgCl}_{2}$ concentration) but modify only critical instrument parameters, such as the annealing temperature of step-down and fluorescence acquisition cycles and extension time at $72^{\circ} \mathrm{C}$.

An initial application of the Chlamydia 23S rRNA real-time PCR detection platform yielded valuable information on the epidemiology of bovine chlamydial infection (data not shown, manuscript submitted). Both the high sensitivity and quantitative aspects of the method proved informative by demonstrating a high prevalence of low-level infection in clinically normal heifers.

\section{ACKNOWLEDGMENTS}

This work was supported by grants from the Public Health Service (grant no. AI-38977 from the National Institute for Allergy and Infectious Disease to B.K.), the Food Animal Health and Disease Research Program at the Auburn University College of Veterinary Medicine (grant no. ALAV-0353 to F.J.D. and B.K.), and the Animal Health Division of Bayer AG., Monheim, Germany (to F.J.D. and B.K.).

\section{REFERENCES}

1.Apfalter, P., F. Blasi, J. Boman, C.A. Gaydos, M. Kundi, M. Maass, A. Makristathis, A. Meijer, et al. 2001. Multicenter comparison trial of DNA extraction methods and PCR assays for detection of Chlamydia pneumoni$a e$ in endarterectomy specimens. J. Clin. Microbiol. 39:519-524.

2.Boman, J., C.A. Gaydos, and T.C. Quinn. 1999. Molecular diagnosis of Chlamydia pneumoniae infection. J. Clin. Microbiol. 37:3791-3799.

3.Chirgwin, J.M., A.E. Przybyla, R.J. MacDonald, and W.J. Rutter. 1979. Isolation of biologically active ribonucleic acid from sources enriched in ribonuclease. Biochemistry 18:5294-5299.

4.Everett, K.D.E. and A.A. Andersen. 1997. The ribosomal intergenic spacer and domain I of the 23S rRNA gene are phylogenetic markers for Chlamydia spp. Int. J. Syst. Bacteriol. 47:461-473.

5.Everett, K.D.E. and A.A. Andersen. 1999. Identification of nine species of the Chlamydiaceae using PCR-RFLP. Int. J. Syst. Bacteriol. 49:803-813.

6.Everett, K.D.E., L.J. Hornung, and A.A. Andersen. 1999. Rapid detection of Chlamydiaceae and other families in the order Chlamydiales: three PCR tests. J. Clin. Microbiol 37:575-580.

7.Hecker, K.H. and K.H. Roux. 1996. High and low annealing temperatures increase both specificity and yield in touchdown and stepdown PCR. BioTechniques 20:478-485.
8.Huang, J., M.-D. Wang, S. Lenz, D. Gao, and B. Kaltenboeck. 1999. IL-12 administered during Chlamydia psittaci lung infection in mice confers immediate and long-term protection and reduces macrophage inflammatory protein-2 level and neutrophil infiltration in lung tissue. J. Immunol. 162:2217-2226.

9.Huang, J., F.J. DeGraves, D. Gao, P. Feng, T. Schlapp, and B. Kaltenboeck. 2001. Quantitative detection of Chlamydia spp. by fluorescent PCRs in the LightCycler. BioTechniques 30:151-157.

10.Johnson, R.E., T.A. Green, J. Schachter, R.B. Jones, E.W. Hook III, C.M. Black, D.H. Martin, M.E. St. Louis, and W.E. Stamm. 2000. Evaluation of nucleic acid amplification tests as reference tests for Chlamydia trachomatis infections in asymptomatic men. J. Clin. Microbiol. 38:4382-4386.

11.Kalman, S., W. Mitchell, R. Marathe, C. Lammel, J. Fan, R.W. Hyman, L. Olinger, J. Grimwood, et al. 1999. Comparative genomes of Chlamydia pneumoniae and $C$. trachomatis. Nat. Genet. 21:385-389.

12.Kaltenboeck, B., K.G. Kousoulas, and J. Storz. 1992. Two-step polymerase chain reactions and restriction endonuclease analyses detect and differentiate ompA DNA of the genus Chlamydia. J. Clin. Microbiol. 30:1098-1104.

13.Kaltenboeck, B., N. Schmeer, and R. Schneider. 1997. Evidence for numerous omp1 alleles of porcine Chlamydia trachomatis and novel chlamydial species obtained by PCR. J. Clin. Microbiol. 35:1835-1841.

14.Smieja, M., J.B. Mahoney, C.H. Goldsmith, S. Chong, A. Petrich, and M. Chernesky. 2001. Replicate PCR testing and probit analysis for detection and quantitation of Chlamydia pneumoniae in clinical specimens. J. Clin. Microbiol. 39:1796-1801.

15.Smith, B., P. Selby, J. Southgate, K. Pittman, C. Bradley, and G.E. Blair. Detection of melanoma cells in peripheral blood by means of reverse transcriptase and polymerase chain reaction. Lancet 338:1227-1229.

16.Stephens, R.S., S. Kalman, C. Lammel, J. Fan, R. Marathe, L. Aravind, W. Mitchell, L. Olinger, et al. 1998. Genome sequence of an obligate intracellular pathogen of humans: Chlamydia trachomatis. Science 282:754759.

17.Vogelstein, B. and D. Gillespie. 1979. Preparative and analytical purification of DNA from agarose. Proc. Natl. Acad. Sci. USA 76:615-619.

Received 16 July 2002; accepted 30 October 2002.

\section{Address correspondence to:}

Dr. Bernhard Kaltenboeck

Department of Pathobiology

College of Veterinary Medicine

Auburn University

270 Greene Hall

Auburn, AL 36849-5519, USA

e-mail:kaltebe@auburn.edu 